\title{
Effects of dietary organic selenium content on fowls, chicks and eggs
}

\author{
ESA KÄÄNTEE, PAAVO KURKELA and KAARLO JAAKKOLA ${ }^{1}$ \\ Food and Public Health Laboratory, SF-61800 Kauhajoki, Finland \\ ${ }^{1}$ Kristiina Medical Centre, SF-64100 Kristiinankaupunki, Finland
}

\begin{abstract}
This study deals with the effects of dietary organic selenium on the condition of parentfowls and offspring, on hatching and on egg $\mathrm{Se}, \mathrm{S}, \mathrm{Fe}, \mathrm{Zn}$ and $\mathrm{Cu}$ contents.

The results showed that selenium contents of 0.14 to $0.85 \mathrm{mg} / \mathrm{kg} \mathrm{DM}$ had no untoward effects on the condition of the animals or on hatching. The selenium contents of eggs and feed were interrelated. An increase in the selenium content of eggs caused no changes in their $\mathrm{S}, \mathrm{Fe}, \mathrm{Zn}$ or $\mathrm{Cu}$ contents.
\end{abstract}

\section{Introduction}

The use of fertilizers containing selenium leads to a substantial increase in selenium levels in plant-based diets, and also increases selenium concentrations in animals fed these diets. Fowls have been found to be extremely sensitive to selenium.

Selenium derived from foodstuffs has a stronger influence on selenium levels in fowls and eggs than corresponding amounts of sodium biselenite (KÄÄNTEE and KURKELA 1980). Marginally toxic amounts of selenium in the diet adversely affect the hatching of eggs (VOKAL-BOREK 1979). This study was carried out to investigate the effects of diets rich in selenium on parent birds, the hatching of eggs, and the offspring of birds fed such diets. The $\mathrm{Se}, \mathrm{Fe}, \mathrm{Zn}, \mathrm{Cu}$ and $\mathrm{S}$ concentrations in eggs were also determined. Particular attention was paid to the possibility of malformations or teratogenic effects. This study is one of a series examining the effects on domestic animals of increases in organic selenium contents of diets as a result of use of fertilizers.

\section{Material}

The birds used in the study were 40 Leghorn hens, each of which was 20 weeks old, and 5 cocks. During the trial, the birds were kept in a $4 \times 3$ metre 
cage with a wooden floor, and equipped with laying nests, automatic drinking fountains and roosts. The animals were fed twice a day, using feeding troughs.

The diet consisted of a concentrate (Table 1), oats meal, poultry calcium and barley flour. The selenium content of the barley flour varied (Table 2). All the barley was grown in one field, various parts of which had been manured using fertilizers containing various amounts of selenium (KORKMAN 1980). Each barley flour was used in the diet for 3 weeks, starting with the flour with the lowest selenium content.

The cage floors were covered with peat litter.

Table 1

\begin{tabular}{lc}
\hline Composition of feed concentrate (air dry) & $\%$ \\
\hline Skim milk powder & 8.0 \\
Fish meal flour & 30.0 \\
Soya grits & 20.0 \\
Food yeast & 6.0 \\
Bone meal (class I quality) & 4.0 \\
Meat and bone meal flour & 10.0 \\
Molasses & 1.0 \\
Powdered hay & 7.4 \\
Central Soyan ABDE -vitamin mixture & 6.0 \\
Food calcium & 4.8 \\
Calcium, Magnesium and Sodium Phosphates & 0.8 \\
Sodium Chloride & 1.525 \\
Magnesium Oxide & 0.147 \\
Copper Sulphate & 0.023 \\
Ferrous Sulphate & 0.098 \\
Potassium Iodide & 0.001 \\
Zinc Sulphide & 0.106 \\
Manganese Oxide & 0.098 \\
Cobalt Sulphate & 0.002 \\
\hline
\end{tabular}

Table 2. Selenium, iron, zinc, copper and sulphur concentrations of oats and barley in this study and concentrations of these elements in Finnish oats and barley according to VARO et al. (1980).

\begin{tabular}{lllll}
\hline & Oats & Barley & $\begin{array}{l}\text { Oats } \\
\text { Varo et al. }\end{array}$ & $\begin{array}{l}\text { Barley } \\
(1980)\end{array}$ \\
\hline $\mathrm{Se}$ & 20 & $340-1400^{*}$ & $4-18$ & $4-26$ \\
$\mathrm{Fe}$ & 120 & $120-125$ & $39-86$ & $44-130$ \\
$\mathrm{Zn}$ & 36 & $24-29$ & $27-43$ & $26-43$ \\
$\mathrm{Cu}$ & 4.7 & $3.8-4.2$ & $3.6-7.4$ & $4.6-9.1$ \\
$\mathrm{~S}$ & 1.7 & $1.3-1.6$ & $1.4-2.0$ & $1.2-1.4$ \\
\hline
\end{tabular}

* Barley intended for use in the study diets was sprayed at the sprouting phase with solutions containing sodium selenite. 


\section{Methods}

The hens and cocks were examined clinically twice a week. Eggs were collected daily. At the end of each 3-week feeding period, 6 eggs. were taken for laboratory examination and 12 eggs for incubation.

At the conclusion of the final feeding period, the cocks were decapitated and their livers, lungs, spleens, testes and hearts, together with samples of their neck muscles removed for laboratory examination.

$\mathrm{Se}, \mathrm{Fe}, \mathrm{Zn}, \mathrm{Cu}$ and $\mathrm{S}$ concentrations in diet, egg and organ samples were determined in the Kemira Company Laboratory, Oulu, using the methods of SAARI and PAASO (1980).

The eggs were incubated at a temperature of $37.5{ }^{\circ} \mathrm{C}$ in an ordinary incubator, in which a shallow vessel of water had been placed. They were turned twice a day during incubation. The chicks and egg contents were investigated clinically after hatching. On the basis of these and earlier results (KÄÄNTEE and KURKELA 1980), correlations between dietary and egg selenium concentrations were assessed.

\section{Results}

The condition of the hens and cocks remained good throughout the trial. The $\mathrm{Se}, \mathrm{S}, \mathrm{Fe}, \mathrm{Zn}$ and $\mathrm{Cu}$ concentrations of diets and eggs after each feeding period are shown in Table 3. The $\mathrm{Se}, \mathrm{Fe}, \mathrm{Zn}, \mathrm{Cu}$ and $\mathrm{S}$ concentrations of the various organs removed from the cocks are shown in Table 5.

Thirty eggs were produced daily during the first trial period. During the second period, production remained unchanged but during the third period there was an increase to 38 eggs a day. During the fourth period, production decreased to 32 eggs daily.

The outcome of incubation, and numbers of dead chicks and nonfertile eggs are shown in Table 4.

All chicks hatched were found to be normal, well developed and healthy. Dead chicks were also normally developed.

The correlation between selenium concentrations in the diet and those in the eggs is shown in Fig. 1.

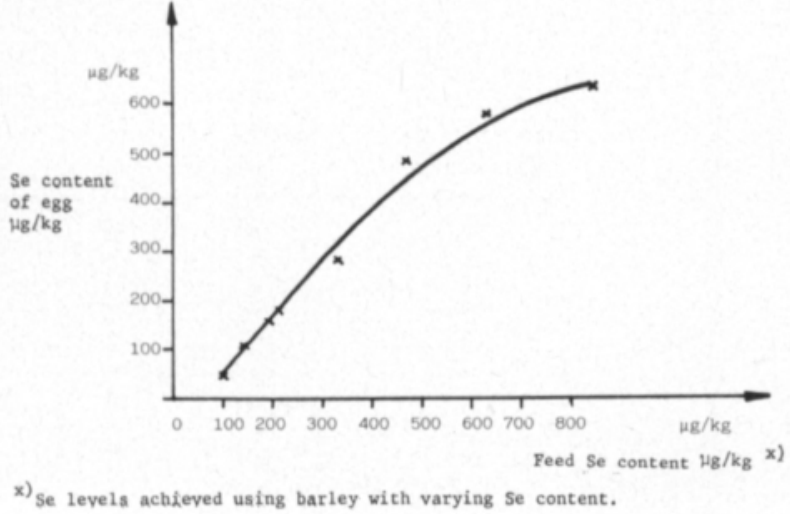

Figure 1. Relationship between dietary Se content and Se levels in eggs. 
Table 3. Effects of dietary selenium, sulphur, iron, zinc and copper levels on the concentrations of these elements in whites of egg and egg yolks.

\begin{tabular}{|c|c|c|c|c|}
\hline \multicolumn{2}{|c|}{$\begin{array}{l}\text { Dietary levels } \\
\mu \mathrm{g} \mathrm{Se} / \mathrm{kg} \mathrm{DM}\end{array}$} & \multirow{2}{*}{$\begin{array}{l}\text { Egg yolk } \\
\mu \mathrm{g} \mathrm{Se} / \mathrm{kg} \text { fresh yolk } \\
285 \pm 90\end{array}$} & \multirow{2}{*}{$\begin{array}{l}\text { White of egg } \\
\mu g \text { Se/kg fresh } \\
\text { white } \\
30 \pm 0\end{array}$} & \multirow{2}{*}{$\begin{array}{l}\text { Whole egg } \\
\mu \mathrm{g} \mathrm{Se} / \mathrm{kg} \text { fresh } \\
\text { contents } \\
113 \pm 25\end{array}$} \\
\hline I & 141 & & & \\
\hline II & 212 & $450 \pm 66$ & $63 \pm 23$ & $180 \pm 21$ \\
\hline III & 333 & $560 \pm 51$ & $142 \pm 15$ & $283 \pm 14$ \\
\hline IV & 850 & $868 \pm 79$ & $540 \pm 88$ & $635 \pm 55$ \\
\hline \multicolumn{2}{|c|}{ g S/kg DM } & g S/kg DM & $\mathrm{g} \mathrm{S} / \mathrm{kg} \mathrm{DM}$ & g S/kg DM \\
\hline I & 3.4 & $4.03 \pm 0.16$ & $18.8 \pm 0.75$ & $13.37 \pm 0.19$ \\
\hline II & 36 & $4.05 \pm 0.31$ & $19.0 \pm 0.63$ & $13.70 \pm 0.47$ \\
\hline III & 3.6 & $3.88 \pm 0.25$ & $17.83 \pm 0.41$ & $13.17 \pm 0.38$ \\
\hline IV & 3.5 & $4.12 \pm 0.24$ & $16.83 \pm 1.94$ & $12.87 \pm 1.49$ \\
\hline \multicolumn{2}{|c|}{$\mathrm{mg} \mathrm{Fe} / \mathrm{kg} \mathrm{DM}$} & $\mathrm{mg} \mathrm{Fe} / \mathrm{kg} \mathrm{DM}$ & $\mathrm{mg} \mathrm{Fe} / \mathrm{kg} \mathrm{DM}$ & $\mathrm{mg} \mathrm{Fe} / \mathrm{kg} \mathrm{DM}$ \\
\hline I & 260 & $157 \pm 10$ & $5.4 \pm 2.8$ & $57 \pm 3.6$ \\
\hline I & 260 & $157 \pm 10$ & $5.4 \pm 2.8$ & $57 \pm 3.6$ \\
\hline II & 215 & $135 \pm 8$ & $4.5 \pm 1$ & $48 \pm 3$ \\
\hline III & 255 & $138 \pm 8$ & $6.8 \pm 1.4$ & $50 \pm 3$ \\
\hline IV & 210 & $133 \pm 5$ & $7.5 \pm 4$ & $48 \pm 4$ \\
\hline \multicolumn{2}{|c|}{$\mathrm{mg} \mathrm{Zn/kg} \mathrm{DM}$} & $\mathrm{mg} \mathrm{Zn/kg} \mathrm{DM}$ & $\mathrm{mg} \mathrm{Zn/kg} \mathrm{DM}$ & $\mathrm{mg} \mathrm{Zn} / \mathrm{kg} \mathrm{DM}$ \\
\hline I & 100 & $86 \pm 7$ & $0.7 \pm 0.3$ & $29 \pm 3$ \\
\hline II & 95 & $83 \pm 10$ & $1.1 \pm 0.6$ & $29 \pm 3$ \\
\hline III & 110 & $92 \pm 3$ & $0.43 \pm 0.3$ & $31 \pm 0.3$ \\
\hline IV & 100 & $87 \pm 2.6$ & $2.2 \pm 2.3$ & $30 \pm 1$ \\
\hline \multicolumn{2}{|c|}{$\mathrm{mg} \mathrm{Cu} / \mathrm{kg} \mathrm{DM}$} & $\mathrm{mg} \mathrm{Cu} / \mathrm{kg} \mathrm{DM}$ & $\mathrm{mg} \mathrm{Cu} / \mathrm{kg} \mathrm{DM}$ & $\mathrm{mg} \mathrm{Cu} / \mathrm{kg} \mathrm{DM}$ \\
\hline I & 14.5 & $2.5 \pm 0.4$ & $<2$ & $0.8 \pm 0.2$ \\
\hline II & 16.8 & $3.1 \pm 0.3$ & $2.1 \pm 0.4$ & $2.5 \pm 0.4$ \\
\hline III & 16.8 & $3.1 \pm 0.2$ & $1.3 \pm 0.3$ & $1.9 \pm 0.2$ \\
\hline IV & 13.5 & $2.8 \pm 0.4$ & $1.7 \pm 0.24$ & $2.95 \pm 0.15$ \\
\hline
\end{tabular}

Table 4. Hatching following each study period

\begin{tabular}{lccc}
\hline Study period & Living chicks & Dead chicks & Nonfertile eggs \\
\hline I & 9 & 1 & 2 \\
II & 8 & 3 & 1 \\
III & 10 & 1 & 1 \\
IV & 8 & 2 & 2 \\
\hline
\end{tabular}


Table 5. Selenium, iron, zinc, copper and sulphur concentrations (in DM) in organs removed from cocks.

\begin{tabular}{lllllr}
\hline ORGAN & $\mu \mathrm{g} \mathrm{Se} / \mathrm{kg}$ & $\mathrm{mg} \mathrm{Fe} / \mathrm{kg}$ & $\mathrm{mg} \mathrm{Zn} / \mathrm{kg}$ & $\mathrm{mg} \mathrm{Cu} / \mathrm{kg}$ & \multicolumn{1}{c}{$\mathrm{g} \mathrm{S} / \mathrm{kg}$} \\
\hline Liver & $2100 \pm 750$ & $560 \pm 95$ & $94 \pm 11$ & $13 \pm 1$ & $10.5 \pm 0.6$ \\
Lungs & $1200 \pm 550$ & $1050 \pm 55$ & $59 \pm 4$ & $<5$ & $10.7 \pm 0.5$ \\
Spleen & $2600 \pm 790$ & $700 \pm 175$ & $86 \pm 13$ & $<5$ & $11 \pm 0.8$ \\
Testis & $2000 \pm 400$ & $140 \pm 30$ & $82 \pm 22$ & $<5$ & $8.7 \pm 0.3$ \\
Neck & $1000 \pm 600$ & $210 \pm 55$ & $175 \pm 22$ & $6.5 \pm 0.9$ & $10.5 \pm 1.0$ \\
Heart & $1200 \pm 450$ & $320 \pm 200$ & $87 \pm 11$ & $10.4 \pm 1.3$ & $9.5 \pm 0.6$ \\
\hline
\end{tabular}

\section{Discussion}

The minimum dietary Se requirement for poultry is $0.03-0.1 \mathrm{mg} \mathrm{Se} \mathrm{per}$ day. The reprided level is $0.15 \mathrm{mg} / \mathrm{kg}$ (VOKAL-BOREK1979). According to nutrient requirements of poultry (ANON 1971), the Se requirements of breeding hens are not known for certain but chicks required $0.1 \mathrm{mg}$ Se in their diet per $\mathrm{kg}$. The dietary $\mathrm{Fe}$ requirement of chicks is $80 \mathrm{mg} / \mathrm{kg}$ in foodstuff, the $\mathrm{Zn}$ requirement $50 \mathrm{mg} / \mathrm{kg}$ and the $\mathrm{Cu}$ requirement $4 \mathrm{mg} / \mathrm{kg}$.

In this study, the dietary Se content was $0.14-0.85 \mathrm{mg} / \mathrm{kg}$ DM in the feed (Table 3). The minimum level was the same as the reprided level according to VOKAL-BOREK (1979) and the maximum level 6 times higher. The S, Fe, $\mathrm{Zn}$ annd $\mathrm{Cu}$ contents of feeds were above the minima required, but remained constant throughout.

\section{Se content of eggs}

The Se content of eggs produced after feeding with the diet lowest in Se $(0.14 \mathrm{mg} / \mathrm{kg} \mathrm{DM}$ in the feed) was $113 \pm 25 \mu \mathrm{g} / \mathrm{kg}$ and was the same as that reported by MORRIS and OLSON (1970) for the Se content of eggs.

The highest Se content of eggs, $635 \pm 55 \mu \mathrm{g} / \mathrm{kg}$, was above the level in eggs from Se-rich areas in the USA $(0.4-0.5 \mathrm{mg} / \mathrm{kg} \mathrm{DM})$ (UNDERWOOD, 1971).

The analytical results for Se contents of eggs in this study were in accordance with results from earlier studies (KÄÄNTEE and KURKELA 1980). On the basis of these results, a graph showing the effect of dietary selenium content on the selenium content of eggs was prepared (Fig. 1).

The $\mathrm{S}, \mathrm{Fe}, \mathrm{Zn}$ and $\mathrm{Cu}$ levels in eggs remained the same throughout. The levels were the same as those found by VARO et al. (1980). The variations in dietary Se content in the present study did not affect the levels of $\mathrm{S}, \mathrm{Fe}, \mathrm{Zn}$ and $\mathrm{Cu}$.

The production of eggs was typical of that normal in hens.

Because only a small number of birds was used, it was not possible to draw more extensive conclusions regarding the effects of dietary selenium levels on egg production. 


\title{
References
}

ANON, 1971. Nutrient Requirements of Poultry. National Academy of Sciences, Washington, 232 pp. HOFFMANN, S., 1978. Über den Mangan, Nickel und Kupfergehalt in Hühnerorganen. Wiener Tierärztl.. Wschr. 65: 260.

KORKMAN, J., 1980. The effect of selenium fertilizers on the selenium content of barley, spring wheat and potatoes. J. Scient. Agric. Soc. Finl. 52: 495-504.

KÄÄNTEE, E. and KURKELA, P., 1980. Comparative effects of barley feed and sodium selenite on selenium levels in hen eggs and tissues. J. Scient. Agric. Sos. Finl. 52: 357-367.

NUURTAMO; M., VARO, P., SAARI, E. and KOIVISTOINEN, P., 1980. Mineral element composition of Finnish foods. V. Meat and meat products. Acta Agr. Scand. Suppl. 22: 57-87.

MORRIS, V. C. and OLSON, O. E., 1970. Selenium content of foods. J. Nutrition 100: 1383-1388.

SAARI, E., and PAASO, A., 1980. Mineral element composition of Finnish foods. II. analytical methods. Acta Agr. Scand. Suppl. 22: 15-25.

UNDERWOOD, E. J., 1971. Trace elements in human and animal nutrition, 3rd Ed. Academic Press, New York, pp. 323-368.

VARO, P., NUURTAMO, M., SAARI; E. and KOIVISTOINEN, P., 1980. Mineral element composition of Finnish foods. VIII. Dairy products, eggs and margarine. Acta Agr. Scand. Suppl. 22: $115-126$.

VOKAL-BOREK, H., 1979. Selenium. University of Stockholm, Institute of Physics. Report 79-16.

WU, S. H., OLDFIELD, J. E., MUTH, O. H., WHANGER, P. D. and WESWIG, P. H., 1973. Effect of selenium, vitamin $\mathrm{E}$ and antioxidants on testicular function in rats. Biol. Reprod. 8: 625-629.

Ms received May 14, 1982.

\section{SELOSTUS}

\section{Rehun orgaanisen seleenipitoisuuden vaikutuksista kanojen ja kanan- poikasten terveydentilaan sekä munien hedelmällisyyteen}

\author{
Esa Kääntee \\ 66270 Pörtom
}

\section{Paavo Kurkela, Kauhajoen elintarvikelaboratorio, 61800 Kauhajoki}

\section{Kaarlo Jaakkola, Kristiinan lääkärikeskus, 64100 Kristiinankaupunki}

Tutkimuksessa tarkastellaan rehun orgaanisen seleenin vaikutusta kanojen terveydentilaan, munien hedelmällisyyteen, poikasten terveydentilaan sekä munien $\mathrm{Se}-, \mathrm{S}-, \mathrm{Fe}, \mathrm{Zn}-\mathrm{ja} \mathrm{Cu}$-pitoisuuksiin.

Tutkimuksiin käytettiin 40 kanaa ja 5 kukkoa. Rehujen seleenipitoisuudet vaihtelivat välillä $0.14 \mathrm{mg} /$ $\mathrm{kg}-0.85 \mathrm{mg} / \mathrm{kg}$ ka:ssa rehua.

Rehun S-pitoisuus oli $3.4-3.6 \mathrm{~g} / \mathrm{kg}$, Fe $210-260 \mathrm{mg} / \mathrm{kg}, \mathrm{Zn} 95-110 \mathrm{mg} / \mathrm{kg}$ ja Cu $13.5-16.8 \mathrm{mg} /$ kg.ka.

Kokeen aikana munien seleenipitoisuus kohosi $113 \pm 25 \mu \mathrm{g} / \mathrm{kg}$ :sta $635 \pm 55 \mu \mathrm{g} / \mathrm{kg}$ :n, mutta haudontatulos pysyi samana.

Kuoriutuneet poikaset olivat terveitä, normaalisti kehittyneitä ja elinvoimaisia.

Munien S-, Fe-, $\mathrm{Zn}$ - ja Cu-pitoisuudet pysyivät koko kokeen ajan samoilla tasoilla.

Tulokset osoittivat, ettei käytetyillä rehun seleenipitoisuuksilla ollut haitallisia vaikutuksia kanoihin eikä kananpoikiin. 